\title{
Supramolecular Assembly of DNA-Phenanthrene Conjugates into Vesicles with Light-Harvesting Properties
}

\author{
Caroline D. Bösch, Jovana Jevric, Nutcha Bürki, Markus Probst, Simon M. Langenegger, and Robert Häner* \\ Department of Chemistry and Biochemistry, University of Bern, Freiestrasse 3, CH-3012 Bern, Switzerland
}

Supporting Information Placeholder

\begin{abstract}
Vesicle-shaped supramolecular polymers are formed by self-assembly of a DNA duplex containing phenanthrene overhangs at both ends. In presence of spermine, the phenanthrene overhangs act as sticky ends linking the DNA duplexes together. In aqueous solution, the assembly leads to vesicles in the range of $50-200 \mathrm{~nm}$, as shown by electron microscopy and dynamic light scattering. Fluorescence measurements show that the assembled phenanthrene units act as light-harvesting antennae and transfer absorbed energy to an acceptor, such as pyrene or Cy3, which can either be directly added to the polymer or attached via a complementary DNA strand. The presence of DNA in the nanostructures allows the construction of light-harvesting vesicles that are amenable to functionalization with different chemical groups.
\end{abstract}

DNA is used to create one-, two-, or three-dimensional assemblies due to its unique molecular recognition properties which opens opportunities to precisely organize functional groups within space. ${ }^{1-9}$ Functional supramolecular assemblies of DNA object have a potential for biomedical, biomimetic and electronic applications. ${ }^{10-18}$ DNA nanostructures can be created by different approaches. DNA origami allows the preparation of well-defined nanometer-sized objects by the folding of long DNAs with the help of guiding oligonucleotide strands. ${ }^{19-24}$ Alternatively, large DNA constructs can be assembled from duplexes with nucleotide overhangs at their ends (sticky ends approach). Two- and three-dimensional structures have been constructed by this approach. ${ }^{25-29}$ Combining the natural nucleotides with chemically modified building blocks $\mathrm{s}^{30-42}$ extends the range of structural and functional features of such nano-objects. Linking hydrophobic molecules onto DNA can lead to the formation of supramolecular polymers in aqueous medium. ${ }^{43}$ Thus, DNA-pyrene hybrid oligomers were shown to self-assemble into nanoribbons with addressable DNA strands at the surfaces. ${ }^{44-46}$ DNA dumbbells with perylenediimides (PDIs) at both ends form one-dimensional DNA supramolecular polymers via PDI stacking. ${ }^{47}$ Similarly, DNA-porphyrin hybrid amphiphiles self-assemble into linear aggregates ${ }^{48}$ and spherical nanostructures. ${ }^{49}$ Furthermore, a cationic dye triplet has been attached as sticky ends on DNA single strands to form long duplexes. ${ }^{50}$

The versatility of DNA assembly makes it also attractive for the arrangement of molecules to construct light-harvesting systems. ${ }^{51-68} \mathrm{We}$ recently described the light-harvesting properties of phenanthrene arrays in DNA-based scaffolds, ${ }^{55,69}$ supramolecular fibres ${ }^{70}$ or nanotubes. ${ }^{71}$ Here, we present the formation and characteristics of lightharvesting vesicles assembled from DNA-phenanthrene conjugates.

Table 1 shows the DNA strands used for this study. The complementary oligomers 1 and 2 contain three 2,7-substituted phenanthrenes at their 3 '-ends. The phenanthrenes are connected via phos- phodiester groups. Hybridization leads to the formation of DNA duplex $1^{*} 2$ containing three phenanthrenes at each end. Oligonucleotides 3 and $\mathbf{4}$ serve as unmodified control sequences.

Table 1. Sequences of oligomers 1-4 and structure of the 2,7substituted phenanthrene building block.

\begin{tabular}{|c|c|}
\hline Strand & Sequence \\
\hline 1 & $5^{\prime}$ CAA GGT CCG ATG CAA GGA AG (Phe $)_{3}$ \\
\hline 2 & $(\mathrm{Phe})_{3}$ GTT CCA GGC TAC GTT CCT TC 5 \\
\hline 3 & 5“ CAA GGT CCG ATG CAA GGA AG 3“ \\
\hline 4 & $3^{\prime}$ GTT CCA GGC TAC GTT CCT TC $5^{\star}$ \\
\hline 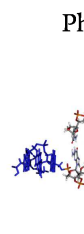 & $\begin{array}{l}\text { Irene }(\mathrm{Phe})=\mathrm{f}^{\circ} \mathrm{=}= \\
\mathrm{I}^{*} 2\end{array}$ \\
\hline
\end{tabular}

Figure 1 shows absorption spectra of duplex $1^{*} 2$ at different temperatures. The bands between 300 and $340 \mathrm{~nm}$ are due to phenanthrene absorption, whereas below $300 \mathrm{~nm}$, the spectrum shows a combination of phenanthrene and the DNA bases. Spectra of duplex $1^{*} 2$ taken under standard conditions ( $10 \mathrm{mM}$ sodium phosphate buffer $\mathrm{pH} 7.0,100 \mathrm{mM} \mathrm{NaCl}$ ) exhibit the expected hypochromicity at 260 $\mathrm{nm}$ upon lowering the temperature (Figure 1, left). The $318 \mathrm{~nm}$ band (phenanthrene absorption only) shows very little changes over the temperature range studied $\left(20-80{ }^{\circ} \mathrm{C}\right)$. Thus, under these conditions interaction between phenanthrene overhangs is negligible. Significant changes in the phenanthrene absorption are, however, observed in the 
presence of spermine tetrahydrochloride (Figure 1, right). A lowering of the temperature leads to a decrease in the absorption of the $318 \mathrm{~nm}$ band as well as a distinct bathochromic shift $(5 \mathrm{~nm})$. Two isosbestic points are observed at $285 \mathrm{~nm}$ and $322 \mathrm{~nm}$. Significant changes are also observed in the region from $240-280 \mathrm{~nm}$, where phenanthrene also shows significant absorption $\left(\lambda_{\max } \sim 274 \mathrm{~nm}^{71}\right)$. This strongly indicates hybridization of the two complementary single strands and, at the same time, aggregation of the phenanthrene units. The effect of polycations on DNA hybridization and aggregation is well documented in the literature. ${ }^{72-76}$ In the present case, spermine seems to facilitate the interaction of the phosphodiester linked phenanthrene residues.
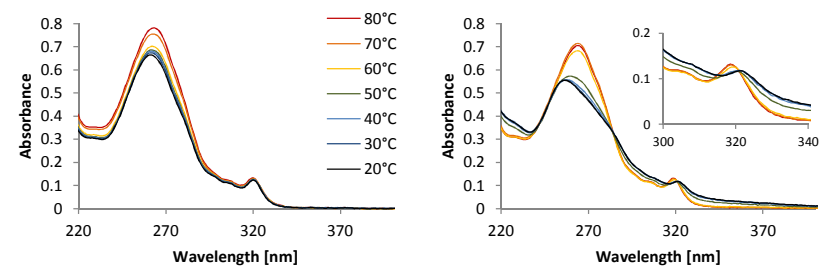

Figure 1. Temperature-dependent absorption spectra of $1^{*} 2(1 \mu \mathrm{M}$ each strand). Left: $10 \mathrm{mM}$ sodium phosphate buffer $\mathrm{pH} 7.0,100 \mathrm{mM}$ $\mathrm{NaCl}$. Right: $10 \mathrm{mM}$ sodium phosphate buffer $\mathrm{pH} 7.0,0.1 \mathrm{mM}$ spermine tetrahydrochloride, 20 vol\% ethanol; inset: enlarged view of the phenanthrene absorption in the $320 \mathrm{~nm}$ region.

Clear evidence for formation of larger aggregates was obtained from atomic force microscopy (AFM), transmission electron microscopy (TEM) and dynamic light scattering (DLS). AFM Images of 1 $\mu \mathrm{M} 1^{*} 2$ on APTES-modified mica reveals micrometer-sized, sheet-like structures with a height of 1.2-1.4 nm (Figure 2A). At higher concentration of $1^{*} 2(5 \mu \mathrm{M})$, however, it becomes obvious that the selfassembly process leads to the formation of vesicles, as shown by AFM (Figure 2B). It is assumed that adsorption of the vesicles existing in solution leads to the formation of a monolayer on the APTES-modified mica. ${ }^{77}$ At high concentration of $\mathbf{1}^{*} \mathbf{2}(5 \mu \mathrm{M})$, a monolayer is first formed on APTES-modified mica. In a second step, intact vesicles are adsorbed on this monolayer. The presence of vesicles with a diameter between 50 and $200 \mathrm{~nm}$ is independently also confirmed by TEM imaging (Figure 2C). These findings are in agreement with DLS measurements which indicate a mean diameter of $110 \mathrm{~nm}$ (see Supporting Information, Figure S29/30). The vesicles are only formed if hybrid $1^{*} 2$ is assembled in the presence of spermine. In the absence of spermine, only small, disparate aggregates are observed (see Supporting Information, Figure S9). Also hybrids $1^{*} 4$ and $2^{*} 3$, which have a phenanthrene overhang just at one end of the DNA duplex, form only illdefined objects smaller than $500 \mathrm{~nm}$ with a variable height (see Supporting Information, Figures S12, S13). Figure 2 gives an illustration of a potential arrangement of DNA and phenanthrenes in the array. The model implies that DNA and phenanthrenes are arranged in alternating bands.
A

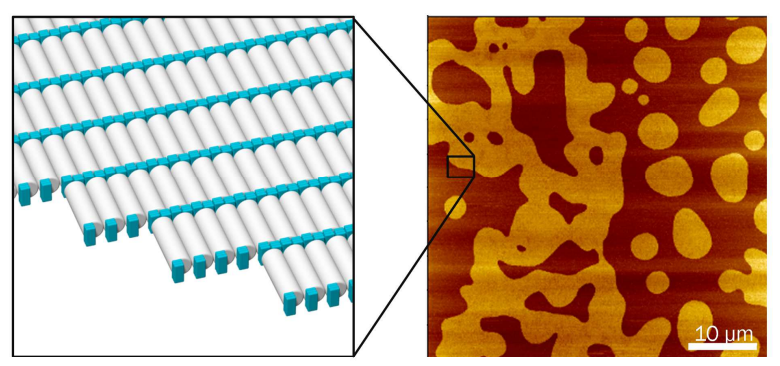

B
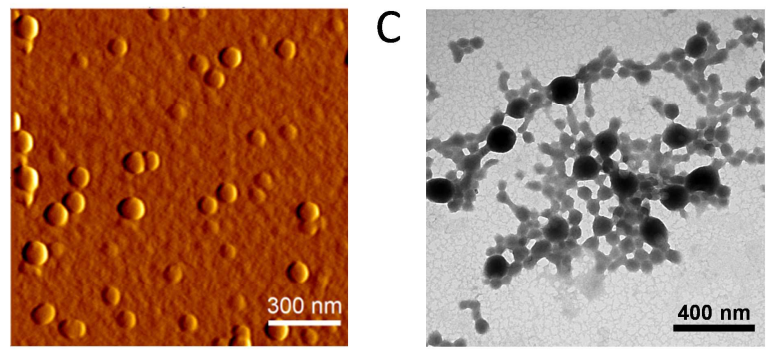

$\mathrm{D}$

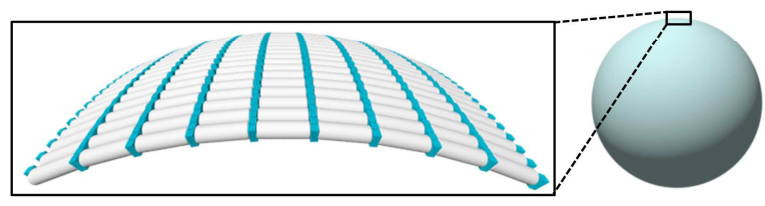

Figure 2. A) AFM image of $1^{*} 2,1 \mu \mathrm{M}$ each strand, deposited on APTES-modified mica (right). Left: Illustration of monolayers of DNA duplexes (light grey) via interaction of phenanthrene sticky ends (blue). B) AFM deflection image $1^{*} 2,5 \mu \mathrm{M}$ each strand, deposited on APTES-modified mica. C) TEM image $1^{*} 2,5 \mu \mathrm{M}$ each strand (carboncoated grid). D) Illustration of vesicle formed by assembly of DNA duplexes with phenanthrene sticky ends. Conditions: $10 \mathrm{mM}$ sodium phosphate buffer $\mathrm{pH} 7.0,0.1 \mathrm{mM}$ spermine tetrahydrochloride, 20 vol\% ethanol.

Fluorescence measurements were performed to further study the phenanthrene aggregates in the observed vesicle. As previously shown, ordered arrays of phenanthrene show efficient excitation energy transfer along $\pi$-stacked assemblies. In combination with pyrene as an acceptor chromophore, the phenanthrene assemblies act as lightharvesting antennae (LHA). ${ }^{55,69-71}$ In order to test if the vesicles assembled from oligomers 1 and 2 also act as LHAs, they were subjected to incorporation of small quantities of pyrene molecules. For this purpose, the vesicle were doped by addition of the pyrene-containing oligomer 5 (Figure 3), which was previously shown to function as an acceptor in the context of tubular phenanthrene supramolecular polymers. ${ }^{71}$ Figure 3 (top) shows the effect of addition of $1 \%$ of pyrene per phenanthrene on the fluorescence spectrum.

Phenanthrene emission ( $378 \mathrm{~nm}$ and $398 \mathrm{~nm}$ ) decreases, whereas pyrene emission ( $412 \mathrm{~nm}, 435 \mathrm{~nm}$ and $462 \mathrm{~nm}$ ) grows. No mentionable pyrene emission occurred if the experiment was performed in the absence of spermine tetrahydrochloride but otherwise identical conditions (see Supporting Information, Figure S3). Additional control 
experiments, such as replacing duplex $1^{*} 2$ with a duplex containing a phenanthrene overhang only at one end $\left(1^{*} 4\right)$ or using only single strand 1 also showed no energy transfer. Incorporation of the pyrenecontaining oligomer 5 into the aggregates formed by hybrid $1^{*} 2$ is significantly improved when the supramolecular polymer is assembled in the presence of 5 (i.e. heating the solution containing oligomers 1, 2 and 5 to $80^{\circ} \mathrm{C}$ and cooling slowly to $20^{\circ} \mathrm{C}$, see Supporting Information). Simple addition of $\mathbf{5}$ to the preformed polymers results in much weaker pyrene fluorescence, suggesting that the phenanthrene aggregates need to be disrupted to allow efficient integration of oligomer 5 .
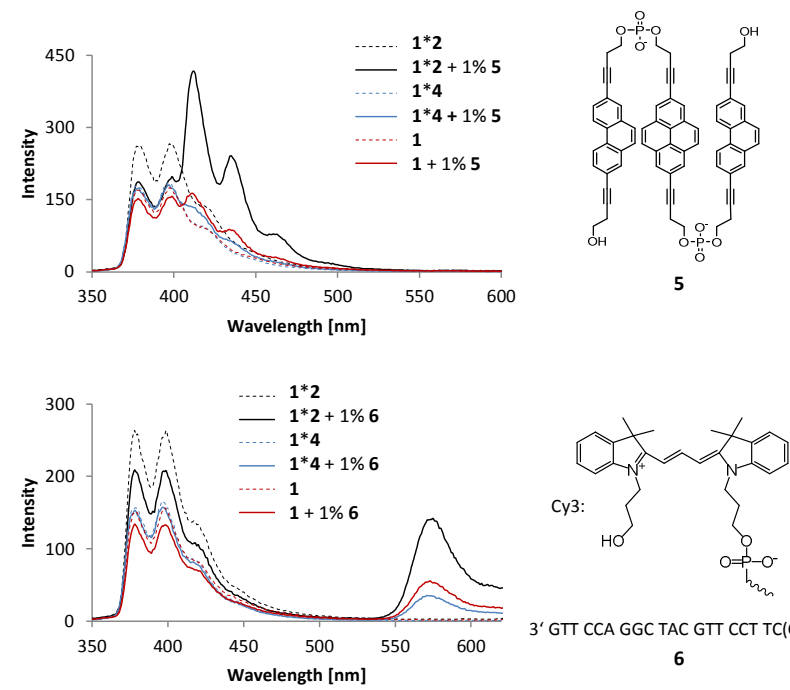

3' GTT CCA GGC TAC GTT CCT TC(CY3)

Figure 3. Fluorescence measurements without (dashed) and with acceptor (solid; $1 \mathrm{~mol} \%$ of acceptor per phenanthrene). Conditions: 1 $\mu \mathrm{M}$ of each strand, $10 \mathrm{mM}$ sodium phosphate buffer $\mathrm{pH}$ 7.0, $0.1 \mathrm{mM}$ spermine tetrahydrochloride, $20 \mathrm{vol} \%$ ethanol, $20^{\circ} \mathrm{C}, \lambda_{\text {exc. }} 321 \mathrm{~nm}$.

The supramolecular polymer can be further functionalized by addition of chemically modified DNA strands. Thus, a cyanine (Cy3) modified oligonucleotide (3'-GTT CCA GGC TAC GTT CCT TCCy3, 6), which is complementary to oligomer 1 , was used as energy acceptor. Energy transfer is observed also in this case (see Figure 3). Cy3 emission at $573 \mathrm{~nm}$ appears while the emission of phenanthrene decreases. Duplex $1^{*} 2$ shows the largest ratio of $\mathrm{Cy} 3$ and phenanthrene emission intensities $(573 / 378 \mathrm{~nm})$. In contrast to the experiments described above with pyrene-containing oligomer 5 , the system with the Cy3-labelled DNA strand 6 does not necessarily need to be heated and cooled to ensure efficient energy transfer (Supporting Information). Obviously, addition of a complementary strand to the supramolecular polymers leads to spontaneous DNA strand exchange. ${ }^{78}$ At $80^{\circ} \mathrm{C}$ no Cy3 emission is observed at all which is in agreement with a complete disassembly of the vesicles resulting in the loss of phenanthrene-to-cyanine energy transfer. Notably, energy transfer is also observed using single strand 1 or duplex $1^{*} 4$, albeit at a reduced level instead of $1^{*} 2$ under otherwise identical conditions (Figure 3). This is explained by hybridization of the cyanine modified oligonucleotide 6 to 1 , either fully in the first case or partially in the latter through strand exchange. In both cases, hybrid $1^{*} 6$ is formed, which is expected to result in energy transfer from phenanthrene to cyanine. In the absence of the light-harvesting antennae $1^{*} 2$, the acceptors exhibit only marginal fluorescence intensities (Supporting Information, Figure S6).
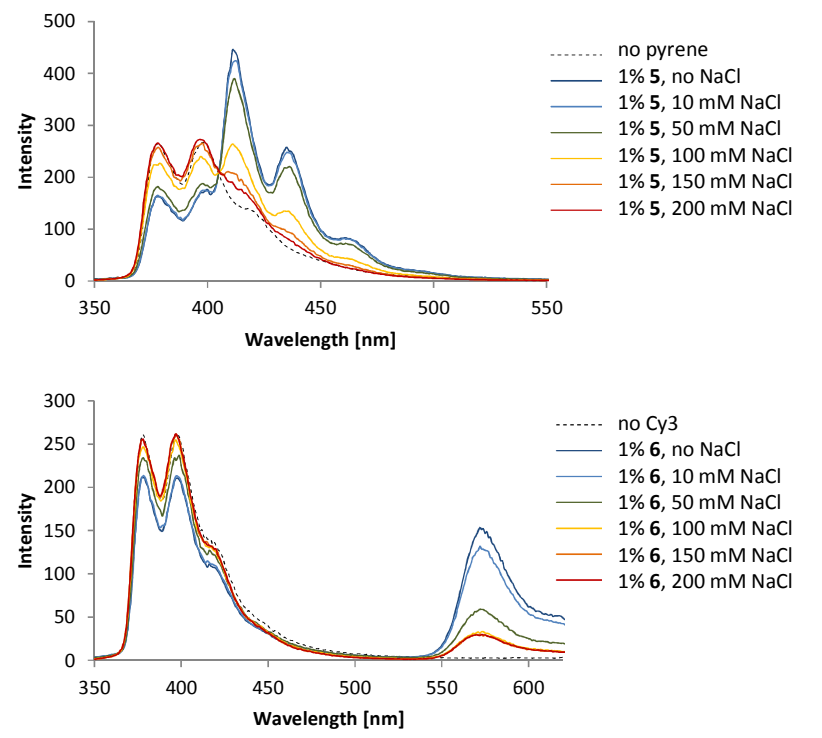

Figure 4: Effect of increasing sodium chloride concentration on energy transfer from phenanthrene to pyrene (top) or Cy3 (bottom); conditions as in Figure 3.

The self-assembly of the vesicles and the resulting light-harvesting properties are reversible; either by heating the solution (as shown in the temperature-dependent UV-vis and fluorescence spectra) or by the addition of sodium chloride. The stabilizing effect of spermine is overridden by increasing the ionic strength (see e.g. ${ }^{79}$ ). Figure 4 shows the fluorescence spectra of pyrene- and Cy3-doped vesicles with increasing concentrations of sodium chloride. In both cases, the emission of the acceptor decreases, whereas phenanthrene emission increases. In vesicles containing pyrene as acceptor, $200 \mathrm{mM} \mathrm{NaCl}$ is required to eliminate pyrene-emission. With oligonucleotide 6 , in which case the acceptor is attached to a DNA strand, the minimal energy transfer is reached at $100 \mathrm{mM} \mathrm{NaCl}$. The residual Cy3-emission is attributed to duplexes formed by single strand 1 and the complementary Cy3strand. Changes upon $\mathrm{NaCl}$ addition are also observed in the absorption spectra (Supporting Information), which show a red-shift in the $260 \mathrm{~nm}$ region and a blue-shift in the $320 \mathrm{~nm}$ region. The changes coincide with the measured absorption of the non-aggregated DNA (measurement at $80^{\circ} \mathrm{C}$, or without spermine). In both measurements the absorption maximum shifts from 257 to $261 \mathrm{~nm}$ by increasing the $\mathrm{NaCl}$ concentration from 50 to $100 \mathrm{mM}$. This leads to the conclusion that the disassembly of the supramolecular aggregates occurs in this $\mathrm{NaCl}$ concentration range.

In conclusion, the formation of supramolecular DNA vesicles via phenanthrene sticky ends has been presented. In the presence of spermine, DNA duplexes with phenanthrene overhangs self-assemble into vesicles with a diameter in the range of $50-200 \mathrm{~nm}$. The assembled phenanthrene units act as light-harvesting antennae and transfer absorbed energy to an acceptor, which can either be directly added to the polymer or attached via a complementary DNA strand. The lightharvesting effect of the vesicles disappears after adding $\mathrm{NaCl}$, which 
leads to the disassembly of the supramolecular aggregates. Duplexes with no or only one phenanthrene overhang do not form assemblies under the same conditions. The described DNA nanoarchitectures allow the construction of light-harvesting supramolecular vesicles that are amenable to functionalization with acceptor molecules at defined distances to the donors by variation of DNA length and sequence. Furthermore, the presence of DNA in the supramolecular polymer opens the possibility of incorporating a diverse range of functionalities.

\section{ASSOCIATED CONTENT}

\section{Supporting Information}

The supporting information is available free of charge via the Internet at http://pubs.acs.org. Materials and general methods; analytical data; UV-vis and fluorescence spectra; additional AFM images.

\section{AUTHOR INFORMATION}

\section{Corresponding Author}

*E-mail: robert.haener@dcb.unibe.ch

\section{Notes}

The authors declare no competing financial interests.

\section{ACKNOWLEDGMENT}

This work was supported by the Swiss National Foundation (Grant 200020-169030 and NCCR MUST).

\section{REFERENCES}

(1) Seeman, N. C. (2003) DNA in a Material World. Nature 421, 427-431.

(2) Seeman, N. C. (2010) Nanomaterials Based on DNA. Annu. Rev. Biochem. 79, 65-87.

(3) Gothelf, K. V.; Labean, T. H. (2005) DNA-Programmed Assembly of Nanostructures. Org. Biomol. Chem. 3, 40234037.

(4) Feldkamp, U.; Niemeyer, C. M. (2006) Rational Design of DNA Nanoarchitectures. Angew. Chem. Int. Ed. 45, 18561876.

(5) Rothemund, P. W. K. (2006) Folding DNA to Create Nanoscale Shapes and Patterns. Nature 440, 297-302.

(6) Jones, M. R.; Seeman, N. C.; Mirkin, C. A. (2015) Programmable Materials and the Nature of the DNA Bond. Science 347, 1260901.

(7) DNA in Supramolecular Chemistry and Nanotechnology (2015), Stulz, E. and Clever, G. H., John Wiley \& Sons, Chichester.

(8) Linko, V.; Dietz, H. (2013) The Enabled State of DNA Nanotechnology. Curr. Opin. Biotechnol. 24, 555-561.

(9) Veneziano, R.; Ratanalert, S.; Zhang, K.; Zhang, F.; Yan, H.; Chiu, W.; Bathe, M. (2016) Designer Nanoscale DNA Assemblies Programmed From the Top Down. Science 352, 1534.

(10) Aldaye, F. A.; Palmer, A. L.; Sleiman, H. F. (2008) Assembling Materials With DNA As the Guide. Science 321, 1795-1799.
(11) Lu, C. H.; Willner, I. (2015) Stimuli-Responsive DNAFunctionalized Nano-/Microcontainers for Switchable and Controlled Release. Angew. Chem. Int. Ed. 54, 12212-12235.

(12) Lu, C. H.; Willner, B.; Willner, I. (2013) DNA Nanotechnology: From Sensing and DNA Machines to Drug-Delivery Systems. Acs Nano 7, 8320-8332.

(13) Bath, J.; Turberfield, A. J. (2007) DNA Nanomachines. Nat. Nanotech. 2, 275-284.

(14) Chakraborty, K.; Veetil, A. T.; Jaffrey, S. R.; Krishnan, Y. (2016) Nucleic Acid-Based Nanodevices in Biological Imaging. Annu. Rev. Biochem. 85, 349-373.

(15) Kumar, V.; Palazzolo, S.; Bayda, S.; Corona, G.; Toffoli, G.; Rizzolio, F. (2016) DNA Nanotechnology for Cancer Therapy. Theranostics 6, 710-725.

(16) Chandrasekaran, A. R. (2016) Programmable DNA Scaffolds for Spatially-Ordered Protein Assembly. Nanoscale 8, 4436-4446.

(17) Yang, Y. R.; Liu, Y.; Yan, H. (2015) DNA Nanostructures As Programmable Biomolecular Scaffolds. Bioconjug. Chem. 26, 1381-1395.

(18) Krasheninina, O.; Novopashina, D.; Apartsin, E.; Venyaminova, A. (2017) Recent Advances in Nucleic Acid Targeting Probes and Supramolecular Constructs Based on Pyrene-Modified Oligonucleotides. Molecules 22, 2108; doi:10.3390/molecules22122108.

(19) Torring, T.; Voigt, N. V.; Nangreave, J.; Yan, H.; Gothelf, K. V. (2011) DNA Origami: a Quantum Leap for SelfAssembly of Complex Structures. Chem. Soc. Rev. 40, 5636-5646.

(20) Sacca, B.; Niemeyer, C. M. (2012) DNA Origami: The Art of Folding DNA. Angew. Chem. Int. Ed. 51, 58-66.

(21) Wang, P.; Meyer, T. A.; Pan, V.; Dutta, P. K.; Ke, Y. (2017) The Beauty and Utility of DNA Origami. Chem 2, 359-382.

(22) Simmel, S. S.; Nickels, P. C.; Liedl, T. (2014) Wireframe and Tensegrity DNA Nanostructures. Acc. Chem. Res. 47, 1691-1699.

(23) Simmel, F. C.; Dittmer, W. U. (2005) DNA Nanodevices. Small 1, 284-299.

(24) Ramakrishnan, S.; Krainer, G.; Grundmeier, G.; Schlierf, M.; Keller, A. (2016) Structural Stability of DNA Origami Nanostructures in the Presence of Chaotropic Agents. Nanoscale 8, 10398-10405.

(25) Seeman, N. C. (1991) Construction of ThreeDimensional Stick Figures From Branched DNA. DNA Cell Biol. 10, 475-486.

(26) Venkadesh, S.; Mandal, P. K.; Gautham, N. (2011) The Sequence D(CGGCGGCCGC) Self-Assembles into a Two Dimensional Rhombic DNA Lattice. Biochem. Biophys. Res. Commun. 407, 548-551.

(27) He, Y.; Chen, Y.; Liu, H. P.; Ribbe, A. E.; Mao, C. D. (2005) Self-Assembly of Hexagonal DNA TwoDimensional (2D) Arrays. J. Am. Chem. Soc. 127, 1220212203. 
(28) Lin, C.; Liu, Y.; Rinker, S.; Yan, H. (2006) DNA Tile Based Self-Assembly: Building Complex Nanoarchitectures. ChemPhysChem 7, 1641-1647.

(29) Ban, E.; Picu, C. R. (2014) Strength of DNA Sticky End Links. Biomacromolecules 15, 143-149.

(30) Teo, Y. N.; Kool, E. T. (2012) DNA-Multichromophore Systems. Chem. Rev. 112, 4221-4245.

(31) Stulz, E. (2017) Nanoarchitectonics With Porphyrin Functionalized DNA. Acc. Chem. Res. 50, 823-831.

(32) Astakhova, I. K.; Wengel, J. (2014) Scaffolding Along Nucleic Acid Duplexes Using 2'-Amino-Locked Nucleic Acids. Acc. Chem. Res. 47, 1768-1777.

(33) Varghese, R.; Wagenknecht, H. A. (2009) DNA As a Supramolecular Framework for the Helical Arrangements of Chromophores: Towards Photoactive DNA-Based Nanomaterials. Chem. Commun. 2615-2624.

(34) Malinovskii, V. L.; Wenger, D.; Häner, R. (2010) Nucleic Acid-Guided Assembly of Aromatic Chromophores. Chem. Soc. Rev. 39, 410-422.

(35) Endo, M.; Sugiyama, H. (2009) Chemical Approaches to DNA Nanotechnology. Chembiochem 10, 2420-2443.

(36) Balaz, M.; Tannir, S.; Varga, K. (2017) Chiral Multichromophoric Supramolecular Nanostructures Assembled by Single Stranded DNA and RNA Templates. Coord. Chem. Rev. 349, 66-83.

(37) Hrdlicka, P. J.; Ostergaard, M. E. (2012) FluorophoreFunctionalised Locked Nucleic Acids (LNAs). RSC Biomol. Sci. 26, 1-33.

(38) Filichev, V. V.; Pedersen, E. B. (2009) DNA-Conjugated Organic Chromophores in DNA Stacking Interactions, in Wiley Encycl.Chem.Biol. (Begley, T. P., Ed.) pp 493-524, Wiley, Hoboken.

(39) Kashida, H.; Liang, X.; Asanuma, H. (2009) Rational Design of Functional DNA With a Non-Ribose Acyclic Scaffold. Curr. Org. Chem. 13, 1065-1084.

(40) Hovelmann, F.; Seitz, O. (2016) DNA Stains As Surrogate Nucleobases in Fluorogenic Hybridization Probes. Acc. Chem. Res. 49, 714-723.

(41) Clever, G. H.; Shionoya, M. (2010) Metal-Base Pairing in DNA. Coord. Chem. Rev. 254, 2391-2402.

(42) Appukutti, N.; Serpell, C. J. (2018) High Definition Polyphosphoesters: Between Nucleic Acids and Plastics. Polym. Chem. doi:10.1039/C8PY00251G.

(43) Krieg, E.; Bastings, M. M. C.; Besenius, P.; Rybtchinski, B. (2016) Supramolecular Polymers in Aqueous Media. Chem. Rev. 116, 2414-2477.

(44) Vyborna, Y.; Vybornyi, M.; Häner, R. (2017) Functional DNA-Grafted Supramolecular Polymers - Chirality, Cargo Binding and Hierarchical Organization. Chem. Commun. 53, 5179-5181.

(45) Vyborna, Y.; Vybornyi, M.; Rudnev, A. V.; Häner, R. (2015) DNA-Grafted Supramolecular Polymers: Helical Ribbon Structures Formed by Self-Assembly of PyreneDNA Chimeric Oligomers. Angew. Chem. Int. Ed. 54, 7934-7938.
(46) Vyborna, Y.; Vybornyi, M.; Häner, R. (2015) From Ribbons to Networks: Hierarchical Organization of DNAGrafted Supramolecular Polymers. J. Am. Chem. Soc. 137, 14051-14054.

(47) Neelakandan, P. P.; Pan, Z.; Hariharan, M.; Zheng, Y.; Weissman, H.; Rybtchinski, B.; Lewis, F. D. (2010) Hydrophobic Self-Assembly of a Perylenediimide-Linked DNA Dumbbell into Supramolecular Polymers. J. Am. Chem. Soc. 132, 15808-15813.

(48) Mammana, A.; Pescitelli, G.; Asakawa, T.; Jockusch, S.; Petrovic, A. G.; Monaco, R. R.; Purrello, R.; Turro, N. J.; Nakanishi, K.; Ellestad, G. A.; Balaz, M.; Berova, N. (2009) Role of Environmental Factors on the Structure and Spectroscopic Response of 5 '-DNA-Porphyrin Conjugates Caused by Changes in the PorphyrinPorphyrin Interactions. Chem. Eur. J. 15, 11853-11866.

(49) Albert, S. K.; Golla, M.; Thelu, H. V. P.; Krishnan, N.; Deepak, P.; Varghese, R. (2016) Synthesis and SelfAssembly of DNA-Chromophore Hybrid Amphiphiles. Org. Biomol. Chem. 14, 6960-6969.

(50) Kashida, H.; Hayashi, T.; Fujii, T.; Asanuma, H. (2011) A Cationic Dye Triplet As a Unique "Glue" That Can Connect Fully Matched Termini of DNA Duplexes. Chem. Eur.J. 17, 2614-2622.

(51) Sancho, O. N.; Browne, W. R.; Roelfes, G. (2013) Hierarchical Self-Assembly of a Biomimetic LightHarvesting Antenna Based on DNA G-Quadruplexes. Chem. Eur.J. 19, 2457-2461.

(52) Dutta, P. K.; Varghese, R.; Nangreave, J.; Lin, S.; Yan, H.; Liu, Y. (2011) DNA-Directed Artificial Light-Harvesting Antenna. J. Am. Chem. Soc. 133, 11985-11993.

(53) Albinsson, B.; Hannestad, J. K.; Boerjesson, K. (2012) Functionalized DNA Nanostructures for Light Harvesting and Charge Separation. Coord. Chem. Rev. 256, 23992413.

(54) Woller, J. G.; Hannestad, J. K.; Albinsson, B. (2013) SelfAssembled Nanoscale DNA-Porphyrin Complex for Artificial Light Harvesting. J. Am. Chem. Soc. 135, 27592768.

(55) Garo, F.; Häner, R. (2012) A DNA-Based LightHarvesting Antenna. Angew. Chem. Int. Ed. 51, 916-919.

(56) Adeyemi, O. O.; Malinovskii, V. L.; Biner, S. M.; Calzaferri, G.; Häner, R. (2012) Photon Harvesting by Excimer-Forming Multichromophores. Chem. Commun. 48, 9589-9591.

(57) Spillmann, C. M.; Ancona, M. G.; Buckhout-White, S.; Algar, W. R.; Stewart, M. H.; Susumu, K.; Huston, A. L.; Goldman, E. R.; Medintz, I. L. (2013) Achieving Effective Terminal Exciton Delivery in Quantum Dot AntennaSensitized Multistep DNA Photonic Wires. Acs Nano 7, 7101-7118.

(58) Kumar, C. V.; Duff, M. (2009) DNA-Based Supramolecular Artificial Light Harvesting Complexes. J. Am. Chem. Soc. 131, 16024-16026.

(59) Cannon, B. L.; Kellis, D. L.; Patten, L. K.; Davis, P. H.; Lee, J.; Graugnard, E.; Yurke, B.; Knowlton, W. B. (2017) 
Coherent Exciton Delocalization in a Two-State DNATemplated Dye Aggregate System. J. Phys. Chem. A 121, 6905-6916.

(60) Olejko, L.; Bald, I. (2017) FRET Efficiency and Antenna Effect in Multi-Color DNA Origami-Based Light Harvesting Systems. RSC Adv. 7, 23924-23934.

(61) Nicoli, F.; Barth, A.; Bae, W.; Neukirchinger, F.; Crevenna, A. H.; Lamb, D. C.; Liedl, T. (2017) Directional Photonic Wire Mediated by Homo-Förster Resonance Energy Transfer on a DNA Origami Platform. Acs Nano 11, 11264-11272.

(62) Klein, W. P.; Diaz, S. A.; Buckhout-White, S.; Melinger, J. S.; Cunningham, P. D.; Goldman, E. R.; Ancona, M. G.; Kuang, W.; Medintz, I. L. (2017) Utilizing HomoFRET to Extend DNA-Scaffolded Photonic Networks and Increase Light-Harvesting Capability. Adv. Opt. Mater. 6, 1700679.

(63) Wang, P.; Gaitanaros, S.; Lee, S.; Bathe, M.; Shih, W. M.; Ke, Y. (2016) Programming Self-Assembly of DNA Origami Honeycomb Two-Dimensional Lattices and Plasmonic Metamaterials. J. Am. Chem. Soc. 138, 77337740.

(64) Garg, V.; Kodis, G.; Liddell, P. A.; Terazono, Y.; Moore, T. A.; Moore, A. L.; Gust, D. (2013) Artificial Photosynthetic Reaction Center With a Coumarin-Based Antenna System. J. Phys. Chem. B 117, 11299-11308.

(65) Li, J.-J.; Chen, Y.; Yu, J.; Cheng, N.; Liu, Y. (2017) A Supramolecular Artificial Light-Harvesting System With an Ultrahigh Antenna Effect. Adv. Mater. 29, 1701905.

(66) Alemán García, M. Á.; Magdalena Estirado, E.; Milroy, L.G.; Brunsveld, L. (2018) Dual-Input Regulation and Positional Control in Hybrid Oligonucleotide/Discotic Supramolecular Wires. Angew. Chem. Int. Ed. 57, 49764980.

(67) Guo, S.; Song, Y.; He, Y.; Hu, X.-Y.; Wang, L. (2018) Highly Efficient Artificial Light-Harvesting Systems Constructed in Aqueous Solution Based on Supramolecular Self-Assembly. Angew. Chem. Int. Ed. 57,3163-3167.

(68) Albert, S. K.; Sivakumar, I.; Golla, M.; Thelu, H. V. P.; Krishnan, N.; Joseph, L.; Ashish; Varghese, R. (2017)
DNA-Decorated Two-Dimensional Crystalline Nanosheets. J. Am. Chem. Soc. 139, 17799-17802.

(69) Probst, M.; Langenegger, S. M.; Häner, R. (2014) A Modular LHC Built on the DNA Three-Way Junction. Chem. Commun. 50, 159-161.

(70) Winiger, C. B.; Li, S.; Kumar, G. R.; Langenegger, S. M.; Häner, R. (2014) Long-Distance Electronic Energy Transfer in Light-Harvesting Supramolecular Polymers. Angew. Chem. Int. Ed. 53, 13609-13613.

(71) Bösch, C. D.; Langenegger, S. M.; Häner, R. (2016) LightHarvesting Nanotubes Formed by Supramolecular Assembly of Aromatic Oligophosphates. Angew. Chem. Int. Ed. 55, 9961-9964.

(72) Oxford Handbook of Nucleic Acid Structure (1999), Neidle, S., Oxford University Press, New York.

(73) Bloomfield, V. A. (1997) DNA Condensation by Multivalent Cations. Biopolymers 44, 269-282.

(74) Iacomino, G.; Picariello, G.; D'Agostino, L. (2012) DNA and Nuclear Aggregates of Polyamines. Biochim. Biophys. Acta - Mol. Cell Res. 1823, 1745-1755.

(75) Zinchenko, A. A.; Yoshikawa, K.; Baigl, D. (2005) DNATemplated Silver Nanorings. Adv. Mater. 17, 2820-2823.

(76) Egli, M. (2002) DNA-Cation Interactions: Quo Vadis? Chemistry \& Biology 9, 277-286.

(77) Goksu, E. I.; Vanegas, J. M.; Blanchette, C. D.; Lin, W. C.; Longo, M. L. (2009) AFM for Structure and Dynamics of Biomembranes. Biochim. Biophys. Acta 1788, 254-266.

(78) Noteborn, W. E. M.; Saez Talens, V.; Kieltyka, R. E. (2017) Reversible Loading of Nanoscale Elements on a Multicomponent Supramolecular Polymer System by Using DNA Strand Displacement. Chembiochem 18, 1995-1999.

(79) Gan, G. L.; Chao, H.; Cai, X. P.; Jiang, Z. S.; Li, H. (2013) Condensation and Salt-Induced Decondensation of DNA Upon Incorporation of a V-Shaped Luminescent $\left[\mathrm{Ru}_{2}(\mathrm{Bpy})_{4}\left(\mathrm{MbpibH}_{2}\right)\right]^{4+}$. J. Inorg. Biochem. 129, 9-14. 
(Phe) ${ }_{3}$ GTT CCA GGC TAC GTT CCT TC 5'

5' CAA GGT CCG ATG CAA GGA AG (Phe) $)_{3}$
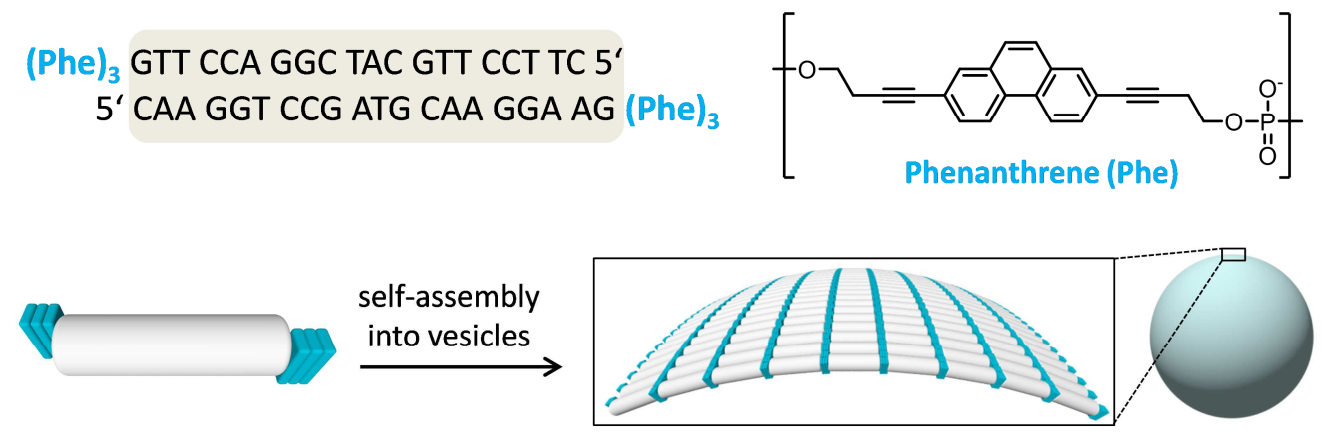